\title{
Reliable and Sensitive Stability Indicating - Liquid Chromato- graphic Method for Determination of Azilsartan Medoxomil and Characterization of Common Hydrolytic Degradation Product
}

\author{
Ramalingam Peraman ${ }^{1}$, SubbaRao Dakinedi ${ }^{2}$, Rajesh Reddy Kadiri ${ }^{* *}$ and Lavanya malineni ${ }^{1}$ \\ 'Division of Pharmaceutical Analysis and Quality Assurance, Raghavendra Institute of Pharmaceutical Education and Research (RIPER), Ananthapuramu (AP), INDIA. \\ 2Department of Chemical Engineering, Jawaharlal Nehru Technological University Anantapur (JNTUA), Anantapuramu (AP), INDIA.
}

\begin{abstract}
Objective: The objective of the proposed method was to develop an accurate, rapid and cost-effective stability indicating a reversed phase high-performance liquid chromatographic method for the determination of azilsartan medoxomil. Materials and Methods: Chromatographic separation of the analyte from its degradation products was achieved on QualisilGold column with a mobile phase composition of Acetonitrile and $0.2 \%$ Triethyl amine[pH 3.0], [62:38\% v/v] at flow rate was $1.0 \mathrm{ml} / \mathrm{min}$, the eluents were monitored using PDA detector at $248 \mathrm{~nm}$. Results: The method was linear $\left(r^{2}=0.9997\right)$ in the concentration range of $20-120 \mu \mathrm{g} / \mathrm{ml}$ with acceptable percentage relative standard deviations for Inter-day (0.22 \%) and Intraday $(0.31 \%)$ precisions. The result for accuracy study was 99.92-100.29 $\%$. Conclusion: The method has proven specificity to quantify azilsartan medoxomil in presence of its degradation products formed in stress studies. Five major degradation products were found in stress studies, among them impurity- 4 was identified and it was also observed that the drug was
\end{abstract}

more susceptible to thermal and photolytic degradations.

Key words: Stability indicating assay, Azilsartan medoxomil, RP-HPLC, ICH guidelines, Forced Degradation, Validation.

\section{Correspondence :}

Rajesh Reddy Kadiri,

Division of Pharmaceutical Analysis and Quality Assurance,

Raghavendra Institute of Pharmaceutical Education and Research (RIPER),

Ananthapuramu (AP), INDIA.

Phone No: +91-9951123235

Email: rajeshreddy.kadhiri@gmail.com

DOI: 10.5530/jyp.2017.9.39

\section{INTRODUCTION}

Azilsartan Medoxomil (AZM), chemically an ester and is named as (5-methyl-2-oxo-1,3-dioxol-4-yl)methyl 2-ethoxy-3-[[4-[2-(5-oxo-2H1,2,4-oxadiazol-3-yl)phenyl] phenyl] methyl] benzimidazole-4-carboxylate (Figure 1). It is approved as selective $\mathrm{AT}_{1}$ subtype angiotensin II receptor antagonist used to treat hypertension. ${ }^{1-3}$ AZM appears as white crystalline powder, practically insoluble in water, freely soluble in methanol, dimethylsulfoxide, and dimethylformamide, soluble in acetic acid, slightly soluble in acetone, acetonitrile and very slightly soluble in tetrahydrofuran and 1-octanol. AZM was approved by the food and drug administration (FDA) in 2011 and available as $80 \mathrm{mg}$ and $40 \mathrm{mg}$ tablets. The literature review on availability of analytical methods for AZM revealed an UV spectroscopic method, ${ }^{4}$ stability indicating high performance thin layer chromatographic (HPTLC) method, ${ }^{5}$ few liquid chromatographic (LC) methods ${ }^{6-11}$ and LC-MS methods ${ }^{12,13}$ for the quantification of AZM in bulk drug, plasma and in combination with other drugs. There are two reports on the estimation of azilsartan medoximil by HPLC $v i z$. Walid et al. and Paras et al. respectively. But these methods were not stability indicating assay method(SIAM). Though reported methods ${ }^{8,9}$ were titled as stability indicating assay, there was no information on degradation data such as \% degradation, mass balance and a number of the degradation product, intrinsic pathway, labile nature of drugs etc. Hence those reported methods are absolutely not reliable for stability indicating purpose. However, Debashish Swain et al. has published an LC/MS compatible method and also LC/MS/MS method for the forced degradation studies of AZM and its potassium salt. ${ }^{13}$ In the article, they had discussed the intrinsic pathway of degradation for the five degradation products formed during the forced degradation study. In fact, there is a significant effect of salts form and stability of drugs and their intrinsic degradation pathway. In the purview of above discussions and based on non-availability of reliable and sensitive stability indicating RP-HPLC method for AZM the present attempt was made to develop SIAM by reversed phase HPLC method and to validate as required by International council on harmonization (ICHQ1) guidelines. Thus the developed method could be more appropriate in the quantification of AZM in presence of all possible degradation products during stability testing protocol.

In this attempt based on the degradation profile, the most common impurity was chemically synthesized, characterized and verified.

\section{MATERIALS AND METHODS}

Standard drug of AZM (99.99 \%) was kindly provided by Aurobindo pharma Pvt limited, Hyderabad(India). HPLC grade solvents were procured from Merck Pvt Ltd, India, and Orthophosphoric acid, Triethyl amine was obtained from Qualigens, Mumbai (India). All glass wares used were calibrated for class A type. Agilent LC 1200 system equipped with photodiode array detector (PDA), EZ chrome elite software, $20 \mu \mathrm{L}$ rheodyne manual injector was used in this study. Chemicals were weighed using calibrated Axis LC GC balance. $\mathrm{pH}$ measurements were performed on Systronics Digital pH meter 802. 


\section{Optimized chromatographic conditions}

The optimum condition for chromatographic analysis of AZM and its degradation products were performed on a reversed-phase LC-GC Qualisil Gold $-\mathrm{C}_{18}(250 \times 4.6 \mathrm{~mm}, 5 \mu$ particle size $)$ column. The mobile phase consisting acetonitrile and $0.2 \%$ triethyl amine buffer ( $\mathrm{pH}$ adjusted to 3.0) at the ratio of $62: 38 \% v / v$ was pumped at $1.0 \mathrm{ml} / \mathrm{min}$ flow rate. The contents of the mobile phase and all samples were filtered through $0.45 \mu$ membrane filter and degassed before analyses. The eluents were monitored at $248 \mathrm{~nm}$ for quantification by diode array detector (DAD). Peak purity was assessed by purity plot. Various experimental trials carried out for the optimization of chromatographic conditions for the analysis of AZM and its degradation products were shown in Table 1. The system suitability parameters of the developed method are shown in Table 2.

\section{Preparation of calibration standards of AZM}

Ten milligrams of AZM was accurately weighed and dissolved in $10 \mathrm{ml}$ of HPLC grade acetonitrile to get $1000 \mu \mathrm{g} / \mathrm{ml}$. From this stock, stock solution working standards ranging from $20-120 \mu \mathrm{g} / \mathrm{ml}$ were prepared in the mobile phase and injected in triplicate. The concentration ( $\mathrm{x}$-axis) versus mean peak area (Y-axis) served as a calibration curve for quantification of AZM. Regression coefficient was used to validate the concentration range and regression equation was used to quantify AZM.

\section{Stress degradation studies of AZM}

Degradation of AZM was performed under neutral, acidic, basic, oxidative, thermal and photolytic stress conditions. ${ }^{14-23}$ Degradation was induced at a concentration of $1000 \mu \mathrm{g} / \mathrm{ml}$. At different time points, $0.5 \mathrm{ml}$ of degraded solution was diluted with mobile phase to $10 \mathrm{ml}(50 \mu \mathrm{g} / \mathrm{ml})$, $\mathrm{pH}$ was adjusted between 3-4 with dil. $\mathrm{HCl} /$ dil. $\mathrm{NaOH}$ and then analyzed. The Blank solutions were also prepared and analyzed under the optimized chromatographic conditions. The chromatogram of blank, dosage form and standard stress solutions were compared to identify the degradation product. The percentage degradation was calculated based on peak area of degraded AZM and peak area of control AZM. Results of degradation studies are shown in Table 3.

\section{Preparation of Stock Solution for stress studies}

Weighed a quantity of $10 \mathrm{mg}$ of AZM was carefully transferred into a $10 \mathrm{ml}$ volumetric flask, dissolved completely in water (for neutral degradation studies) and the volume was made up to get $1000 \mu \mathrm{g} / \mathrm{ml}$. The same procedure was used to prepare stock solutions for stress studies viz for acid hydrolysis, base hydrolysis, and oxidation respectively with $\mathrm{HCl}$ $(0.1 \mathrm{~N}), \mathrm{NaOH}(0.05 \mathrm{~N})$ and hydrogen peroxide $(0.3 \%)$. Thermal degradation was carried out for solid State AZM by heating the samples over a period in a hot air oven, at $70^{\circ} \mathrm{C}$. Photo-degradation was carried on solid Sample by exposing to natural sunlight. Blank was analyzed under the same condition to assess the method specificity.

\begin{tabular}{|c|c|c|c|c|}
\hline No & $\begin{array}{l}\text { Mobile phase composition } \\
\text { (at } 1.0 \mathrm{ml} / \mathrm{min} \text { flow rate) }\end{array}$ & $\begin{array}{l}\text { Retention time }\left(t_{R}\right) \\
\text { in } \min \end{array}$ & Asymmetry & Theoretical plates \\
\hline 1 & Methanol: water (70:30) & 4.720 & 0.74596 & 445 \\
\hline 2 & Methanol: water $(60: 40 \% \mathrm{v} / \mathrm{v})$ & 12.927 & 0.83374 & 444 \\
\hline 3 & Methanol: water (0.2\%TEA, pH 3.0 with OPA) $(80: 20 \%$ v/v) & 6.187 & 0.84630 & 1434 \\
\hline 4 & Methanol: water (0.2\%TEA, pH 3.0 with OPA) $(70: 30 \% \mathrm{v} / \mathrm{v})$ & 14.187 & 0.68493 & 849 \\
\hline 5 & Acetonitrile: water $(70: 30 \% \mathrm{v} / \mathrm{v})$ & 5.207 & 1.24005 & 5450 \\
\hline 6 & Acetonitrile: water $(65: 35 \% \mathrm{v} / \mathrm{v})$ & 6.393 & 1.14274 & 5360 \\
\hline 7 & Acetonitrile: water $(60: 40 \% \mathrm{v} / \mathrm{v})$ & 7.407 & 1.32444 & 1993 \\
\hline 8 & Acetonitrile: water (0.2\%TEA,pH 3.0 with OPA) $(70: 30 \% \mathrm{v} / \mathrm{v})$ & 5.187 & 1.23314 & 5520 \\
\hline 9 & Acetonitrile: water $(0.2 \% \mathrm{TEA}, \mathrm{pH} 3.0$ with OPA $)(65: 35 \% \mathrm{v} / \mathrm{v})$ & 6.233 & 1.15822 & 5180 \\
\hline 10 & Acetonitrile: water $(0.2 \%$ TEA pH 3.0 with OPA $)(62: 38 \% \mathrm{v} / \mathrm{v})$ & 7.353 & 1.05959 & 5190 \\
\hline 11 & Acetonitrile: water (0.2\% TEA pH 7.0 with OPA) $(62: 38 \% \mathrm{v} / \mathrm{v})$ & 7.956 & 1.4773 & 4190 \\
\hline
\end{tabular}

Table 2: System suitability parameters for the developed method (AZM)

\begin{tabular}{cc}
\hline Parameters & Results \\
\hline Chromatographic column & Qualisil Gold C18 $(250 \times 4.6 \mathrm{~mm}$ i.d, $5 \mu \mathrm{m})$ \\
Mobile phase $^{*}$ & Acetonitrile and water $(0.2 \% \mathrm{TEA}, \mathrm{pH} 3.0$ with OPA $)$ at the ratio of \\
& $62: 38 \% \mathrm{v} / \mathrm{v})$ \\
Flow rate & $1 \mathrm{ml} / \mathrm{min}$ \\
Detection wavelength & $248 \mathrm{~nm}$ \\
Retention time $\left(\mathrm{t}_{\mathrm{R}}\right)$ & $7.3 \pm 0.1 \mathrm{~min}$ \\
Tailing factor & $1.12 \pm 0.01$ \\
Theoretical plates & $>5000$ \\
Repeatability (\% RSD $)$ & 0.45 \\
Impurity Retention minutes & $2.7,3.3,3.9,4.5,5.0 \mathrm{~min}$ \\
Resolution AZM from & $>2$ \\
impurities & \\
\hline
\end{tabular}


Table 3: Stress Degradation Profile of AZM

\begin{tabular}{|c|c|c|c|c|c|c|c|c|c|}
\hline \multirow{2}{*}{$\begin{array}{c}\text { Stress } \\
\text { Conditions }\end{array}$} & \multirow{2}{*}{$\begin{array}{l}\text { Dura- } \\
\text { tion }\end{array}$} & \multicolumn{7}{|c|}{ Degradation data } & \multirow{2}{*}{$\begin{array}{c}\begin{array}{c}\text { Mass } \\
\text { balance }\end{array} \\
\%\end{array}$} \\
\hline & & $\begin{array}{c}\operatorname{Imp} \\
1\end{array}$ & $\begin{array}{c}\operatorname{Imp} \\
2\end{array}$ & $\begin{array}{c}\operatorname{Imp} \\
3\end{array}$ & $\begin{array}{c}\operatorname{Imp} \\
4\end{array}$ & $\begin{array}{c}\operatorname{Imp} \\
5\end{array}$ & $\begin{array}{l}\text { Degra-dants } \\
(\%)\end{array}$ & $\begin{array}{c}\text { AZM } \\
(\%)\end{array}$ & \\
\hline Water at RT & 8 days & -- & -- & -- & Yes & -- & 11.41 & 88.52 & 99.93 \\
\hline $0.1 \mathrm{~N} \mathrm{HCl}$ at $\mathrm{RT}$ & 5 days & -- & -- & -- & Yes & -- & 22.48 & 77.31 & 99.79 \\
\hline $0.05 \mathrm{~N} \mathrm{NaOH}$ at $\mathrm{RT}$ & $20 \mathrm{~min}$ & -- & -- & -- & Yes & -- & 20.51 & 79.31 & 99.82 \\
\hline $0.3 \% \mathrm{H}_{2} \mathrm{O}_{2}$ & $2 \mathrm{~h}$ & Yes & -- & -- & Yes & -- & 26.04 & 72.95 & 98.99 \\
\hline Thermal $\left(105^{\circ} \mathrm{C}\right)$ & $6 \mathrm{~h}$ & -- & Yes & Yes & Yes & Yes & 28.17 & 71.63 & 99.80 \\
\hline Photolytic & $30 \mathrm{~min}$ & Yes & Yes & -- & Yes & -- & 33.52 & 66.17 & 99.69 \\
\hline Retention time & -- & $2.7 \pm 0.1$ & $3.3 \pm 0.1$ & $3.9 \pm 0.1$ & $4.5 \pm 0.1$ & $5.0 \pm 0.1$ & -- & -- & -- \\
\hline
\end{tabular}

\section{Hydrolysis}

Stock solutions of $1000 \mu \mathrm{g} / \mathrm{ml}$ were prepared in $0.05 \mathrm{~N} \mathrm{NaOH}$ (Basic), $1 \mathrm{~N} \mathrm{HCl}$ (Acidic) and water (neutral) at room temperature. Samples from acid hydrolysis were neutralized with $0.1 \mathrm{~N} \mathrm{NaOH}$ and the samples from base hydrolysis were neutralized with $0.05 \mathrm{~N} \mathrm{HCl}$. For acid and neutral degradation, the samples were withdrawn periodically at $0,1,24,48 \mathrm{~h}$ and for up to 8 days. The solutions were then suitably diluted to obtain $(50 \mu \mathrm{g} / \mathrm{ml})$ and injected under optimized chromatographic conditions with appropriate blank and control. For alkaline degradation studies the samples were withdrawn at 0 and $20 \mathrm{~min}$, suitably diluted and analyzed by the optimized chromatographic method.

\section{Oxidation}

Stock solutions of $1000 \mu \mathrm{g} / \mathrm{ml}$ were prepared $0.3 \%$ hydrogen peroxide at room temperature. $0.5 \mathrm{ml}$ volume of sample was withdrawn at different time points viz. $0,30,60,90$ and $120 \mathrm{~min}$, diluted to $10 \mathrm{ml}$ with mobile phase $(50 \mu \mathrm{g} / \mathrm{ml})$ and analyzed by the optimized chromatographic conditions against the suitable blank solution.

\section{Thermal degradation}

$100 \mathrm{mg}$ of AZM in a dry Petri dish was exposed to heat in a hot air oven at $70^{\circ} \mathrm{C}$. At various time intervals $(0,1,3,6 \mathrm{~h}), 10 \mathrm{mg}$ of the heated solid samples were weighed, suitably dissolved, then diluted with mobile phase to get a concentration of $50 \mu \mathrm{g} / \mathrm{ml}$ and analyzed by the optimized chromatographic method.

\section{Photo degradation}

Photo degradation studies were carried out by exposing the powder sample under sunlight for $8 \mathrm{hrs}$. at various time intervals $(0,1,3$ and $6 \mathrm{hrs}), 10 \mathrm{mg}$ of the solid samples were weighed, suitably dissolves, then diluted with mobile phase to get a concentration of $50 \mu \mathrm{g} / \mathrm{ml}$ and analysed by the optimised chromatographic method.

\section{Preparation of sample solution}

Twenty tablets were weighed and powdered. A quantity of powder equivalent to $50 \mathrm{mg}$ of AZM was weighed accurately and transferred to a $100 \mathrm{ml}$ volumetric flask. A small quantity of methanol was added to dissolve and sonicated for $15 \mathrm{~min}$. The volume was made up to the mark with the same solvent and filtered through a $0.45 \mu$ filter to give $500 \mu \mathrm{g} / \mathrm{ml}$ of AZM. $1 \mathrm{ml}$ of the above solution was further diluted to $10 \mathrm{ml}$ with mobile phase and analyzed. The results of the assay are shown in Table 4.

\section{Method validation}

The developed method was validated as per ICH Q2 guidelines ${ }^{24}$ for various validation parameters viz specificity, selectivity, linearity, precision,
Table 4: Validation parameters for the developed method (AZM)

\begin{tabular}{|c|c|}
\hline Parameters & Results \\
\hline Specificity & $7.3 \pm 0.1 \mathrm{~min}(\mathrm{ASM})$ \\
\hline Selectivity & $2.7,3.3,3.9,4.5,5.0 \mathrm{~min}$ (impurities) \\
\hline Linearity & $20-120 \mu \mathrm{g} / \mathrm{ml}\left(\mathrm{r}^{2}: 0.9997\right)$ \\
\hline Repeatability & $0.45 \%$ (RSD) \\
\hline \multicolumn{2}{|l|}{ Precision } \\
\hline a. Intraday & $0.19-0.39 \%(\mathrm{RSD})$ \\
\hline b. Inter-day & $0.14-0.28 \%$ (RSD) \\
\hline \multicolumn{2}{|l|}{ Accuracy by \% Recovery } \\
\hline $80 \%$ level & $100.24 \%$ (RSD: $0.21 \%$ ) \\
\hline $100 \%$ level & $99.92 \%$ (RSD: $0.25 \%)$ \\
\hline $120 \%$ level & $100.29 \%$ (RSD: $0.41 \%$ ) \\
\hline LOD & $0.0186 \mu \mathrm{g} / \mathrm{ml}$ \\
\hline LOQ & $0.0613 \mu \mathrm{g} / \mathrm{ml}$ \\
\hline Assay (tablets) & 99.64\% (RSD: 0.28 \%) \\
\hline \multicolumn{2}{|l|}{ Robustness } \\
\hline$\%$ Organic phase (3 \%) & $1.63 \%(\mathrm{RSD})$ \\
\hline $\mathrm{pH}$ (0.2 units) & $1.33 \%(\mathrm{RSD})$ \\
\hline Flow rate $(0.1 \mathrm{ml} / \mathrm{min})$ & $2.14 \%(\mathrm{RSD})$ \\
\hline
\end{tabular}

accuracy, limit of detection, limit of quantification and robustness. The results were shown in Table 4.

\section{RESULTS}

\section{Method optimization}

AZM was optimized at $7.4 \pm 0.1$ min with acceptable plate count $(>5000)$ and asymmetric factor (1.05). The method was validated for its specificity for AZM in presence of its degradation products. In stress sample run, it was observed that five major degradation products were formed with a retention time of $2.7 \pm 0.1 \mathrm{~min}$ (Impurity- 1), $3.3 \pm 0.1 \mathrm{~min}$ (Impurity- 2), $3.9 \pm 0.1 \mathrm{~min}$ (Impurity- 3), $4.5 \pm 0.1 \mathrm{~min}$ (Impurity- 4), and 5.0 $\pm 0.1 \mathrm{~min}$ (Impurity- 5). The peak purity and resolution among the impurities were good. The $\%$ of impurities formed and \% degradation of the drug and corresponding mass balances were detailed in Table 3. Mass balance was calculated based on $\%$ area normalization method. 


\section{Validation of the method}

The method was validated for all validation parameters as per ICH Q2 guidelines. ${ }^{24}$ The specificity of the method was good and it was proven by analyzing stress sample. The resolution between AZM and its degradation products were more than 2 . The peak purity was assessed by purity plot and was found to be satisfactory in all stress studies.

The linearity for AZM was established in the range of $20-120 \mu \mathrm{g} / \mathrm{ml}$. The correlation coefficient $\left(\mathrm{r}^{2}\right)$ was found to be 0.9997 . The precision study was carried out at $25,50,75 \mu \mathrm{g} / \mathrm{ml}$. The $\%$ RSD values for inter and intraday precision were less than 1 indicating that method is highly precise. The accuracy of the method was validated by recovery studies and was found to significant and within the specification limits, with \% recovery ranging from $99.92-100.29 \%$ (within the acceptable range $98-102 \%$ ). The assay result for the marketed tablet was found to be $99.64 \%$ (i.e. within $95-105 \%$ ) with \% RSD of $0.28 \%$. LOD and LOQ of the method for AZM were $0.0186 \mu \mathrm{g} / \mathrm{ml}$ and $0.0613 \mu \mathrm{g} / \mathrm{ml}$, respectively.

The robustness of the developed method was determined by analyzing the samples under a variety of conditions of the method parameters, such as a change in flow rate $( \pm 0.1 \mathrm{ml} / \mathrm{min}), \mathrm{pH}$ of the buffer ( \pm 0.2 units), mobile phase composition $( \pm 2 \%)$ and wavelength $( \pm 2 \mathrm{~nm})$. The $\%$ RSD for robust studies for the standard sample was found to less than 2, indicating that method is robust. Validation result of the method proved that the developed method is specific, accurate, precise and robust for stability indicating assay of AZM. Results of validation data were shown in Table 4.

\section{Identification of Hydrolytic impurity (Impurity-4)}

With reference to the impurity - 4 at $4.5 \mathrm{~min}$, chemical synthesis was carried out in $10 \% \mathrm{NaOH}$ under reflux, in order to completely hydrolyze azilsartan medoxamil to azilsartan and medoxamil. The formed crude product was recrystallized with ethanol. The reduction in retention time is due to increased polarity of azilsartan (impurity-4) as compared to AZM. The compound was spiked with standard AZM and injected into the system. The retention of synthesized impurity -4 (azilsartan) was similar that of impurity formed in hydrolysis. Further, the structure of impurity (Figure. 1) was confirmed by IR, $\mathrm{H}^{1}-\mathrm{NMR}$, and C13 NMR data. The absence of proton signal at $2.81 \mathrm{ppm}\left(-\mathrm{CH}_{3}\right)$ and $4.92 \mathrm{ppm}$ $\left(-\mathrm{O}-\mathrm{CH}_{2}-\right)$ indicated that an ester hydrolysis (-COO-) has been taken place. Further, $\mathrm{C}^{13}$-NMR spectra supported the absence of a signal at $16.2 \mathrm{ppm}\left(-\mathrm{CH}_{3}\right)$ and $16.0 \mathrm{ppm}\left(-\mathrm{O}-\mathrm{CH}_{2}-\right)$ for a medoxamil moiety. In addition, a proton signal around $10.9 \mathrm{ppm}$ indicated the formation of - $\mathrm{COOH}$ (azilsartan).

\section{DISCUSSION}

In the preliminary experimental run, AZM was separated on C18 column with trials using a mobile phase consisting of water and methanol at a different ratio. The drug was found to be retained, but the plate count was less than 1000 with very poor tailing factor. Considering Benz imidazole and oxdiazole cores in the chemical structure, $0.2 \%$ triethylamine (TEA) was used as the aqueous phase at a $\mathrm{pH}$ of 3.0. As a result, retention was further increased with minor improvement in plate count and tailing factor. Then, the mobile phase was switched over to the composition containing acetonitrile and water at a different ratio. With acetonitrile, it was noted that peak shape was good with plate count of more than 5000 . But still, the tailing factor was more than 1.5. To achieve better specificity and to avoid method failure in stress studies, $0.2 \%$ TEA in water ( $\mathrm{pH}$ adjusted to 3.0 with ortho phosphoric acid) was used as an aqueous phase. Change in $\mathrm{pH}$ to 7.0, reduced the platelet count and increased the tailing factor. Unlike other methods, in this method phosphate buffers were avoided, to make this method as LC-MS compatible. Finally, the optimized method arrived at $62: 38 \% v / v$. of acetonitrile and $0.2 \%$
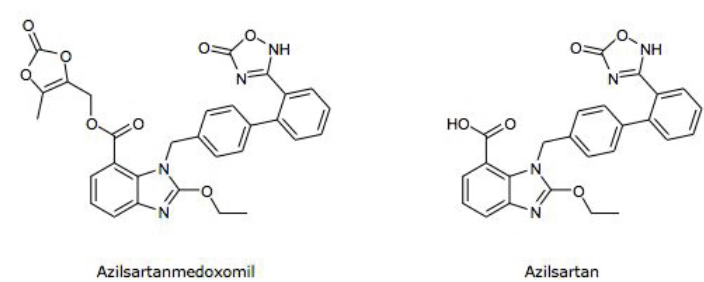

Figure 1: Chemical structure of azilsartan medoxomil (AZM) and azilsartan (Impurity-4)



Figure 2(a): Optimized chromatogram of Azilsartan Medoxomil on C18 column (AZM)

Figure 2(b): Chromatogram of acid degradation in $0.1 \mathrm{~N} \mathrm{HCl}$ at 5 days Figure 2(c): Chromatogram of alkaline degradation in $0.05 \mathrm{~N} \mathrm{NaOH}$ at $20 \mathrm{~min}$ Figure 2(d): Chromatogram of neutral degradation in $\mathrm{pH} 7$ water at 8 days

triethyl amine buffer ( $\mathrm{pH}: 3.0)$ at $1 \mathrm{ml} / \mathrm{min}$ flow rate by PDA detection. The experimental trials and system suitability parameter of the method were shown in Table 1 and Table 2. The developed method has explored five major impurities, Viz2.7 $\pm 0.1 \mathrm{~min}$ (Impurity- 1), $3.3 \pm 0.1 \mathrm{~min}$ (Impurity- 2), 3.9 $\pm 0.1 \mathrm{~min}$ (Impurity- 3), 4.5 $\pm 0.1 \mathrm{~min}$ (Impurity- 4), and $5.0 \pm 0.1 \mathrm{~min}$ (Impurity- 5). The system suitability parameters satisfied the regulatory requirement to quantify AZM in the degraded sample. The detailed discussion on degradation is appended below.

\section{Acid induced Degradation (0.1 N HCl for 5 days)}

AZM was degraded to $22.48 \%$ with one degradation product (impurity-4) at retention times of $4.5 \pm 0.1 \mathrm{~min}$. The assay AZM was $77.31 \%$ and the chromatogram is shown in Figure 2(b).

\section{Base induced degradation (0.05 N NaOH for $20 \mathrm{~min}$ )}

AZM was degraded to $20.51 \%$ with one degradation product (impurity-4) at retention times of $4.5 \pm 0.1 \mathrm{~min}$. The assay AZM was $79.31 \%$ and the chromatogram is shown in Figure 2(c).

\section{Neutral Degradation (water $\mathrm{pH}: 7.0 \pm 0.2$ for 8 days)}

AZM was degraded to $11.48 \%$ with one degradation product (impurity-4) at retention times of $4.5 \pm 0.1 \mathrm{~min}$. The assay AZM was $88.52 \%$ and the chromatogram is shown in Figure 2(d).

\section{Oxidative degradation $\left(0.3 \% \mathrm{H}_{2} \mathrm{O}_{2}\right.$ for $2 h$ )}

AZM showed two degradation products at $2.7 \pm 0.1 \mathrm{~min}$ (impurity-1) and $4.5 \pm 0.1 \mathrm{~min}$ (impurity -4 ). Total degradation was found to be $26.04 \%$ whereas AZM assay value was $72.95 \%$ and the chromatogram is shown in Figure 3(a). 


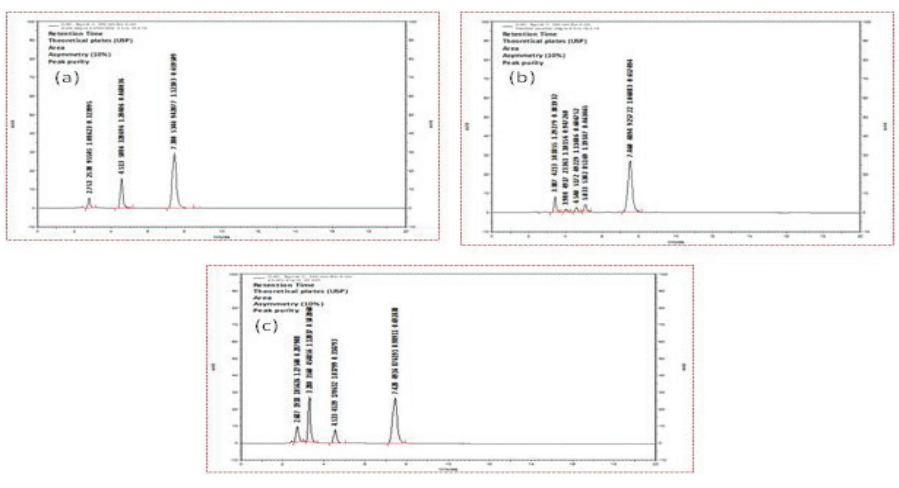

Figure 3(a): Chromatogram of oxidative degradation in $0.3 \% \mathrm{H}_{2} \mathrm{O}_{2}$ at $2 \mathrm{~h}$

Figure $3(\mathbf{b})$ : Chromatogram of thermal degradation $\left(105^{\circ} \mathrm{C}\right)$ at $6 \mathrm{~h}$

Figure 3(c): Chromatogram of photo degradation at $30 \mathrm{~min}$

\section{Thermal degradation (dry heat at $105^{\circ} \mathrm{C} 6 \mathrm{~h}$ )}

Four impurities were formed in thermal degradation of solid AZM at $105^{\circ} \mathrm{C}$ with retention times of $2.7 \pm 0.1 \mathrm{~min}$ (Impurity- 1), $3.3 \pm 0.1 \mathrm{~min}$ (Impurity- 2), 4.5 $\pm 0.1 \mathrm{~min}$ (Impurity- 4) and 5.0 $\pm 0.1 \mathrm{~min}$ (Impurity- 5). Total degradation was found to be $28.17 \%$ whereas AZM assay value was 71.63\%. The chromatogram is shown in Figure 3(b).

\section{Photolytic degradation (sunlight for $30 \mathrm{~min}$ )}

AZM was exposed to photolytic degradation in sunlight for a period of $30 \mathrm{~min}$. the degradation was observed with three degradation products with retention times of $3.3 \pm 0.1 \mathrm{~min}$ (Impurity- 2), 3.9 $\pm 0.1 \mathrm{~min}$ (Impurity-3), $4.5 \pm 0.1 \mathrm{~min}$ (Impurity- 4) and 5.0 $\pm 0.1 \mathrm{~min}$ (Impurity- 5). The assay of AZM in photo degraded sample was $66.17 \%$ and the chromatogram is shown in Figure 3(c).

Ester hydrolysis will be a most common intrinsic pathway of AZM, the impurity formed will be its parent drug. The developed method has shown very high resolution between Azilsartan (4.9 mins) and AZM (7.3 mins), and thus method is highly reliable to quantify AZM and its hydrolytic products.

To summarize, AZM was labile for all conditions. AZM was found to be more extremely unstable in the base and relatively more stable in acid and neutral $\mathrm{pH}$. Susceptible nature of AZM is due to ester functional group present in the chemical structure. It was noticed that there was only one degradation product formed in acidic, basic and neutral conditions. Thus impurity-4 (4.5 $\pm 0.1 \mathrm{~min})$ formed under all three conditions, could be azilsartan (a hydrolysed product of ester) which was supported by spectral studies. The other product of ester hydrolysis (5-methyl2-oxo-1,3-dioxol-4-yl)methanol, was not detected due to the absence of conjugated system or weak Chromophore or due to further hydrolysis of dioxol group. The mass balances were found to be more than $98 \%$ indicated that the method is suitable for detection of all possible impurities. The Impurity-3 (at $3.9 \mathrm{~min}$ ) was found to a specific impurity formed in thermal degradation. Impurity -2 (3.2 $\mathrm{min})$ was the major impurity found in photolytic degradation. Resolutions among these impurities were satisfactory. Resolution of AZM from degradation products were more than 4. All degradation products were eluted before 5.0 mins whereas AZM was eluted at $7.3 \mathrm{~min}$.

\section{CONCLUSION}

A new specific stability indicating RP-HPLC method was developed for the estimation of AZM in the pharmaceutical dosage form and validated according to $\mathrm{ICH}$ guidelines. The method was found to be specific for the detection of all possible impurities in the dosage form under various conditions and accurate, precise and robust for the assay of AZM in dosage forms.

\section{ACKNOWLEDGEMENT}

The authors wish to thank Aurobindo Pharmaceutical private limited, Hyderabad, India for the provided standard sample of AZM.

\section{CONFLICT OF INTEREST}

No conflict of interest are declared.

\section{ABBREVIATIONS}

AZM: Azilsartan Medoxomil; ICH: International Council on Harmonization; RP-HPLC: Reverse Phase High Performance Liquid Chromatography; FDA: Food and Drug Administration; SIAM: Stability Indicating Assay Method; LOD: Limit of Detection; LOQ: Limit of Quantification; RSD: Relative Standard Deviation.

\section{REFERENCES}

1. European medicines evaluation agency (EMEA). Assessment report Edarbi azilsartan medoxomil Procedure No: EMEA/H/C/002293. United Kingdom, 2011

2. U.S. Food and Drug Administration (FDA). FDA approves Edarbi to treat high bloodpressure" (Press release). February 25, 2011.

3. Bakris GL, Sica D, Weber M, White WB, Roberts A, Perez A, et al. The comparative effects of azilsartan medoxomil and olmesartan on ambulatory and clinic blood pressure. J Clin Hypertens. 2011;13(2):81-8.

4. Raja G. New Simple UV Spectrophotometric Method for Determination of Azilsartan medoxomil in Bulk and Pharmaceutical dosage forms. Int J Pharm Biol Sci. 2013;4(4):1133-7.

5. Raja G, Sreenivasulu B, Srinivas G, Sreenivas N, Hemant Kumar S, Raghu Babu K. A simple and sensitive stability-indicating HPTLC assay method for the determination of azilsartan medoxomil. Indo American $\mathrm{J}$ of Pharmaceutical Research. 2014;4(6):2985-92.

6. Madhu Babu K, Bikshal Babu. Reverse phase-HPLC method development and validation for the simultaneous estimation of Azilsartan medoxomil and chlortalidone in pharmaceutical dosage form. Jamonline. 2012;2(1):117-26.

7. Naazneen S, Sridevi A. Stability - indicating RP - HPLC method for the simultaneous estimation of azilsartan medoxomil and chlorthalidone in solid dosage forms. Int J Pharm Pharm Sci. 2014;6(6):236-43.

8. Srinivasan R, Kamal CJ, Rajesh G, Dushyanth K. Stability - indicating RP - HPLC method for the determination of azilsartan medoxomil in bulk and dosage forms. Int J Pharm Anal Res. 2014;3(4):445-52.

9. Masthanamma SK, Pradeephti J. Stability Indicating RP-HPLC method for determination of Azilsartan medoxomil in Pharmaceutical dosage form. Res $J$ Pharm Technol. 2014;7(2):168-72.

10. Ebeid WM, Elkady EF, El-Zaher AA, El-Bagary RI, Patonay G. Stability-indicating RP-LC method for determination of azilsartan medoxomil and chlorthalidone in pharmaceutical dosage forms: application to degradation kinetics. Anal Bioanal Chem. 2014;406(26):6701-12.

11. Vekariya PP, Joshi HS. Development and validation of RP-HPLC method for azilsartan medoxomil potassium quantitation in human plasma by solid phase extraction procedure. ISRN Spectroscopy. 2013;1-6. doi:10.1155/2013/572170.

12. Sreenivasulu J, Venkata RP, Sampath KRG, Nagaraju HVS, Thirumalai RS, Eswaraiah S. A Rapid Novel HPLC Method for Estimation of Eight Related Compounds in Azilsartan Kamedoxomil and Identification of Degradation Compounds by Using LC-MS. J Chromatogr Sci. 2015; doi: 10.1093/chromsci/ bmv039 First published online: April 29.

13. Swain D, Sahu G, Samanthula G. Rapid LC-MS Compatible Stability Indicating Assay Method for Azilsartan Medoxomil Potassium. J Anal Bioanal Tech. 2015;6:254 doi: 10.4172/2155-9872.1000254.

14. Charde MS, Jitendra K, Welankiwar AS, Chakole RD. Development of forced degradation studies of drugs. International Journal of Advances in Pharmaceutics. 2013;2(3):34-9.

15. Brummer H. How to approach a forced degradation study. Life Science Technology Bulletin. 2011;31:1-4.

16. Reynolds DW, Facchine KL, Mullaney JF. Available guidance and best practices for conducting forced degradation studies. Pharm Tech. 2002; 26(2): 48-56

17. International Council on Harmonisation $(\mathrm{ICH})$ Harmonized tripartite guidelines. Photo-stability testing of new drug substances and products. Q1B, 1993

18. International Council on Harmonisation $(\mathrm{ICH})$ Harmonized tripartite guidelines. Stability testing of new drug substances and products. Q1A(R2), 1995.

19. Mallikarjunarao N, Gowrisankar D. Development and Validation of Stability Indicating RP-HPLC Method for Simultaneous Estimation of Paracetamol and 
Flupirtine maleate in Pure and Pharmaceutical Dosage Forms. J Young Pharm. $2015 ; 7(2): 81-8$

20. Shrivastava A, Issarani R, Nagori BP. Stability indicating high-performance liquid chromatography method for the estimation of artemether in capsule dosage forms. J Young Pharm. 2010;2(1):79-84.

21. Rao KS, Jena N, Rao ME. Development and validation of a specific stability indicating high performance liquid chromatographic method for valsartan. J Young Pharm. 2010;2(2):183-9.
22. Saptarini NM, Warya S, Sari AD, Setyarini A. Stability Studies of Amoxicillin and Gentamicin Injection in Intravenous Infusions. J Young Pharm. 2015;7(3):251.

23. Kulyadi GP, Sathyanarayana MB. Stability indicating HPTLC determination of triamcinalone acetonide in bulk drug and sterile injectable suspension. J Young Pharm. 2016;8(4):430.

24. International Council on Harmonisation $(\mathrm{ICH})$ Harmonized tripartite guidelines. Validation of Analytical Procedures: Text and Methodology. Q2(R1), 1995.

Article History: Submission Date: 06-10-16; Received Date: 19-11-16; Acceptance Date: 28-12-16.

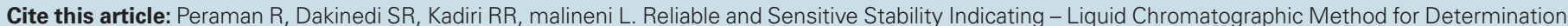
of Azilsartan Medoxomil and Characterization of Common Hydrolytic Degradation Product. J Young Pharm. 2017;9(2):197-202. 